\title{
A Review of the Production Cycle of Titanium Dioxide Pigment
}

\author{
Manuel Jesús Gázquez',2*, Juan Pedro Bolívar1, Rafael Garcia-Tenorio³, Federico Vaca1 \\ ${ }^{1}$ Departamento de Física Aplicada, Universidad de Huelva, Huelva, España \\ ${ }^{2}$ Departamento de Química, Proyecto Prometeo, Universidad Técnicas Particular de Loja (UTPL), Loja, Ecuador \\ ${ }^{3}$ Departamento de Física Aplicada II, Universidad de Sevilla, Sevilla, España \\ Email: "
}

Received 19 March 2014; revised 23 April 2014; accepted 2 May 2014

Copyright (C) 2014 by authors and Scientific Research Publishing Inc.

This work is licensed under the Creative Commons Attribution International License (CC BY).

http://creativecommons.org/licenses/by/4.0/

(c) $\underset{\mathrm{EY}}{\mathrm{O}}$ Open Access

\section{Abstract}

Titanium is a very important element for several industrial applications, being one of the ninth most abundant elements in the Earth's crust (0.63\% wt). In this work it will discuss the different mining and industrial activities involved in the production of titanium dioxide. The first step analyzed will treat about the beneficiation mining process of titanium mineral, and secondly, it will discuss the two main processes of the $\mathrm{TiO}_{2}$ manufacturing (sulphate and chloride routes). In addition, we will show different uses of the titanium dioxide pigment as filler in paper, plastics and rubber industries and as flux in glass manufacture, etc. Finally, we will show that the old wastes are currently called co-products since they were valorized, being commercialized by the Spanish industry of $\mathrm{TiO}_{2}$ production in different fields such as agriculture, civil engineering, or cement manufacturing.

\section{Keywords}

Titanium Minerals, Titanium Dioxide Pigment, Properties and Uses of Tio 2 , Valorization of Co-Products

\section{Titanium Minerals: Origin, Deposits and Resources}

Titanium was discovered in 1791 by the British clergyman and mineralogist William Gregor while analyzing black magnetic sands from Menachan in Cornwall (England). He produced a white metallic oxide from the mineral menachanite, a variety of ilmenite, and named the new element menachite. A few years after Gregor's discovery, M.H. Klaproth, a German chemist, separated $\mathrm{TiO}_{2}$ from the mineral rutile. Klaproth named the new

\footnotetext{
${ }^{*}$ Corresponding author.
} 
element titanium after the giants of Greek mythology. In 1825, J.J. Berzelius, a Swedish chemist, performed a crude separation of titanium metal. However, it was not until 1910 that M.A. Hunter, an American chemist, produced pure titanium. Ilmenite, the principal titanium ore mineral, was named after the Ilmen Mountains in the south Urals.

Titanium, with atomic number 22 and symbol Ti, is one of the transition elements in Group IVB of the periodic table. Its chemistry shows many similarities to those of silicon and zirconium, although its aqueous solution chemistry shows some resemblances to those of vanadium and chromium. Titanium is a silver-white metallic element with a low density, good strength, excellent corrosion resistance, very low electrical and thermal conductivity, and is paramagnetic. Titanium is as strong as steel but $45 \%$ lighter. It is $60 \%$ heavier than aluminum, but twice as strong. Titanium has a lower coefficient of expansion and lower thermal conductivity than either steel or aluminum alloys. Pure titanium is malleable and ductile but it becomes brittle when contaminated with other elements such as carbon and nitrogen. It can be polished to a high luster. The natural titanium consists of five stable isotopes, ${ }^{46} \mathrm{Ti}(8 \%),{ }^{47} \mathrm{Ti}(7.3 \%),{ }^{48} \mathrm{Ti}(73.8 \%),{ }^{49} \mathrm{Ti}(5.5 \%)$ and ${ }^{50} \mathrm{Ti}(5.4 \%)$, but several unstable isotopes (radioactive) are also known, being ${ }^{51} \mathrm{Ti}$, the radioactive isotope with highest half-live $(5.76 \mathrm{~min})$.

Titanium is not found as a pure metal in nature due to its strong affinity for oxygen, carbon and nitrogen, making it difficult to obtain in the pure state, but it suffers the phenomenon of "passivation", which is the process of making a material "passive", usually by the deposition of a layer of oxide that adheres to the metal surface [1]. In the context of corrosion, passivation is the spontaneous formation of a hard non-reactive surface film that inhibits further corrosion. This oxide or nitride film usually has a thickness of few nanometers.

\subsection{Titanium Resources}

Titanium is the ninth most abundant element in the earth's crust representing approximately 0.6 percent and the seventh metal most abundant in the whole Earth [2] [3] which is found in practically all rocks and sediments, and is present in plants, animals and natural waters. Its elemental abundance is about five times smaller than iron and 100 times greater than copper. Ti metal use is about 200 times less than copper and 2000 times less than iron. The commercial production of titanium dioxide started on the 1920 decade, and the Ti metal started on the 1950 decade due to the increase of demand generated by the aircraft industry, reaching its metal production 166,000 metric tons in 2008 [4]. Titanium ores are basically found in nature as mainly ilmenite (the most important economic mineral), see Figure 1, nominally $\mathrm{FeTiO}_{3}$ but often altered, either as a rock or as sand, rutile (Figure 2(a)), anatase (Figure 2(b)) and brookite, (Figure 2(c)), which although they all have the same formula, differ in their crystalline structure and also as leucoxene $\left.\left(\mathrm{Fe}_{2} \mathrm{O}_{3} \cdot \mathrm{nTiO}\right)_{2}\right)$ [5], an oxidation product of ilmenite which it is composed of finely crystalline rutile.

The mineralogical properties of the main titanium minerals are summarized in Table 1.

In addition, titanium is common in magnetite, with Ti-rich $(2 \%-20 \%)$ varieties termed titaniferous magnetite or titanomagnetite. Other less common titanium oxide-bearing minerals are pseudobrookite $\left(\mathrm{Fe}_{2} \mathrm{TiO}_{5}\right)$, perovskite $\left(\mathrm{CaTiO}_{3}\right)$, geikielite $\left((\mathrm{Mg}, \mathrm{Fe}) \mathrm{TiO}_{3}\right)$, and pyrophanite $\left(\mathrm{MnTiO}_{3}\right)[6]$. The only silicate mineral with titanium as a major component is titanite, formerly called sphene.

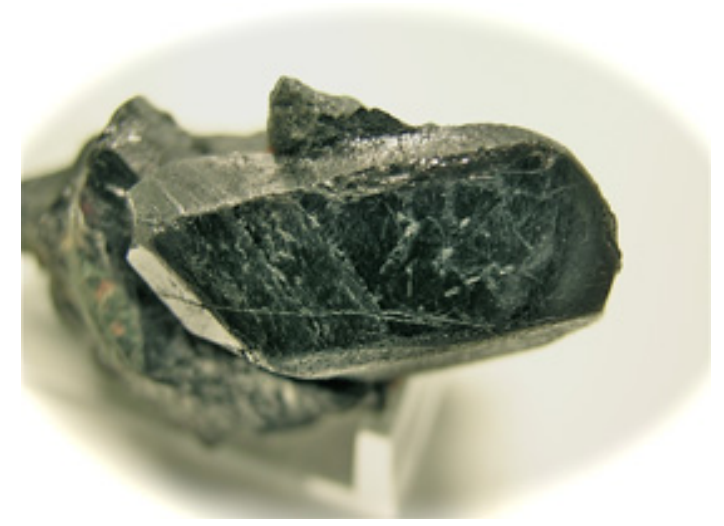

Figure 1. Ilmenite ore. Picture obtained from virtual museum of the University of Huelva. 


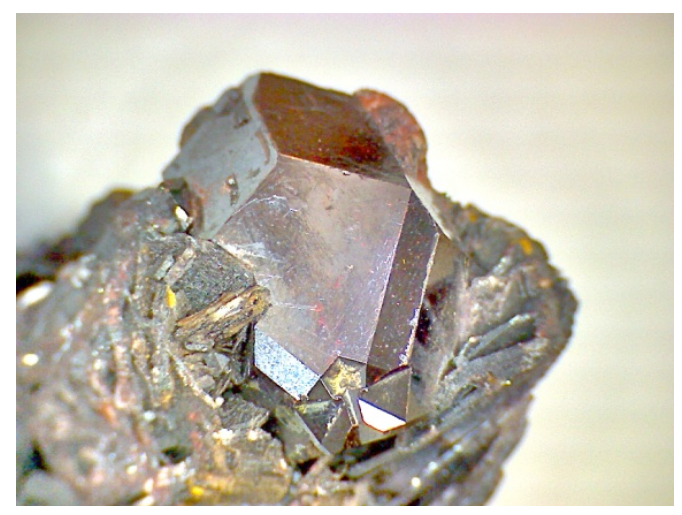

(a)

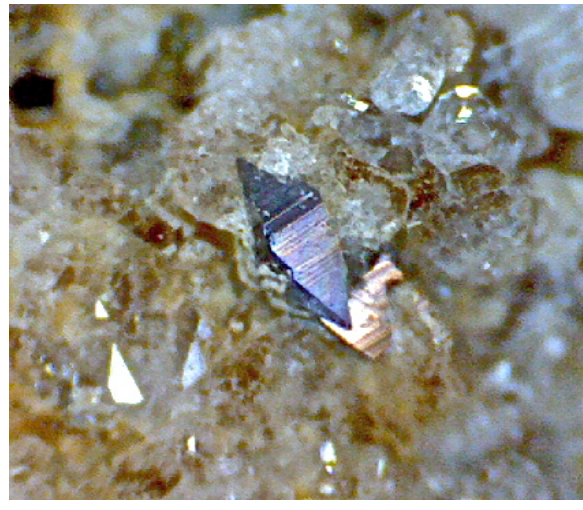

(b)

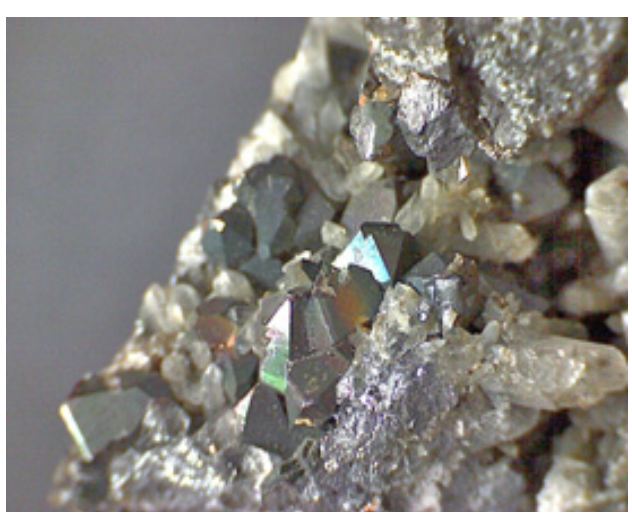

(c)

Figure 2. a) Rutile form; b) Anatase form; c) Brookite form. Pictures obtained from virtual museum of the University of Huelva.

Table 1. Properties of some minerals of titanium [7].

\begin{tabular}{|c|c|c|c|c|c|c|}
\hline Name, (Formula) & $\% \mathrm{TiO}_{2}$ & Colour & Hardness & Density & Crystal Form & Transparency \\
\hline $\begin{array}{l}\text { Ilmenite } \\
\left(\mathrm{FeTiO}_{3}\right)\end{array}$ & 52.6 & black & $5-6$ & $4.5-5.0$ & hexagonal & opaque \\
\hline $\begin{array}{l}\text { Perovskite } \\
\left(\mathrm{CaTiO}_{3}\right)\end{array}$ & 58 & $\begin{array}{l}\text { Black, Brown, } \\
\text { reddish-brown or yellow }\end{array}$ & 5.5 & $4.48-4.26$ & $\begin{array}{c}\text { Monoclinic } \\
\text { (pseudocubic) }\end{array}$ & \\
\hline $\begin{array}{c}\text { Rutile, anatase, } \\
\text { brookite } \\
\left(\mathrm{TiO}_{2}\right)\end{array}$ & 95 & $\begin{array}{l}\text { reddish-brown, red, } \\
\text { yellowish or black }\end{array}$ & $\begin{array}{c}6.0-6.5 \text { (rutile) } \\
5.5-6.0 \\
\text { (anatase and } \\
\text { brookite) }\end{array}$ & $\begin{array}{c}4.23-5.5 \text { (rutile) } \\
3.82-3.97 \\
\text { (anatase) and } \\
4.08-4.18 \\
\text { (brookite) }\end{array}$ & $\begin{array}{c}\text { Tetragonal (rutile, } \\
\text { anatase) } \\
\text { Orthorhombic } \\
\text { (brookite) }\end{array}$ & $\begin{array}{c}\text { opaque or } \\
\text { subtransparent }\end{array}$ \\
\hline $\begin{array}{l}\text { Titanite (sphene) } \\
\left(\mathrm{CaTiSiO}_{5}\right)\end{array}$ & $35-40$ & $\begin{array}{l}\text { Brown, green, grey, } \\
\text { yellow or black }\end{array}$ & $5.0-5.5$ & & monoclinic & $\begin{array}{l}\text { transparent to } \\
\text { opaque }\end{array}$ \\
\hline
\end{tabular}

One of the most important sources of titanium is the black mineral sands deposits, which contain mainly heavy minerals with a specific gravity greater than 2.85 , and they generally consist of two ore product streams; firstly, titanium dioxide in the rutile form, ilmenite and leucoxene and, secondly, zircon. Ilmenite is used in its natural form and also to manufacture titanium slag and synthetic rutile products as we will see later, Section 2.2.

\subsection{Main Deposits}

The geology of titanium mineral deposits was reviewed by Force [8], and their world production and reserves has been summarized by Gambogui in different years (2009, 2010, and 2011) [4] [9] [10]. More than half of the world's titanium production is from ilmenite and rutile in shoreline placer deposits in Australia, South Africa, USA, India and Sri Lanka. Most of the remainder is supplied by magmatic ilmenite deposits in Canada, Norway, 
Finland and USA. The magmatic deposits yield ilmenite with a $\mathrm{TiO}_{2}$ content of $35 \%-40 \%$, whereas the shoreline placer deposits provide ilmenite of higher $\mathrm{TiO}_{2}$ content, including altered ilmenite $\left(60 \%-75 \% \mathrm{TiO}_{2}\right)$, leucoxene $\left(76 \%-90 \% \mathrm{TiO}_{2}\right)$ and rutile $\left(95 \% \mathrm{TiO}_{2}\right)[11]$.

In this sense, the most significant class of magmatic ilmenite deposits is associated with anorthosite or anorthosite-gabbro complexes ${ }^{1}$, mostly of Precambrian age. These ores typically occur in ilmenite-rich lenses, dikes and sills cutting the anorthosites, and of lesser importance, disseminated in the anorthosites. The ilmenite probably crystallized from an immiscible iron-titanium-rich heavy liquid phase of a ferrodiorite magma [8], which formed syngenetic layers and segregations, as well as auto-intrusions into partly or wholly solidified anorthosite-gabbro. Minerals include ilmenite, titaniferous magnetite (with exsolved titanhematite and ulvospinel), plagioclase, pyroxene, olivine, garnet, biotite, apatite, rutile and pyrrhotite. In a second class of magmatic deposits, perovskite, rutile, brookite and/or ilmenite occur in alkalic ring complexes predominantly composed of nepheline syenites, but are particularly associated with pyroxenite phases.

The titanium minerals mostly occur in magnetite-perovskite dikes intruding pyroxenite (Pyroxenite is a plutonic rock that consists of dark minerals in the pyroxene group plus a little olivine or amphibole minerals). The presence of $\mathrm{Nb}, \mathrm{REE}$ and $\mathrm{Th}$ in the oxide minerals of this class of deposit makes refining difficult and there is currently no commercially operating process for recovery of $\mathrm{TiO}_{2}$ from perovskite. On the other hand, some alkalic anorthositic complexes have contact metasomatic deposits of rutile on their margins. Significant tonnages of rutile ore may be developed where swarms of anorthosite dikes and sills permeate country rocks, as in the Roseland District, Virginia [8].

Moreover, we have to take in to account the importance of the alluvial placer deposits. Rutile has been mined from Quaternary alluvial deposits in the Gbangbama district of Sierra Leone, where the deposits are mostly about $10 \mathrm{~m}$ and up to $20 \mathrm{~m}$ thick, and lie directly on bedrock.

In addition, rutile along with zircon and ilmenite is mined from several Quaternary beach and dune heavymineral sand deposits along the east coast of Australia, from Tomago near Newcastle in the south, to North Stradbroke Island, near Brisbane [12]. From the north of Stradbroke Island to Gladstone, the proportion of ilmenite increases at the expense of rutile and zircon. On the west coast of Australia, ilmenite, leucoxene, rutile, zircon and monazite are recovered from Pliocene and Quaternary shoreline deposits, mainly near Bunbury in the south and at Eneabba $225 \mathrm{~km}$ north of Perth [13].

In South Africa, heavy-mineral deposits occur in Holocene high dunes at Richards Bay, about $160 \mathrm{~km}$ north of Durban. In the USA, Pleistocene beach deposits in Jacksonville District, Florida (Trail Ridge and Green Cove Springs), produce ilmenite, a leucoxene-rutile mixture, and rutile, with zircon, staurolite and monazite as coproducts. Nearby modern beach deposits were mined in the past. Undeveloped resources are known in Georgia, Tennessee and the Carolinas. India produces ilmenite and rutile from beach deposits near Quilon and Manavalakurichi on the south-western coast. Large deposits have also been reported in the Chatrapur area. Malaysia and Thailand produce small quantities of titanium minerals as by-products from shoreline placer tin mining.

Sand ilmenite placer deposits have been formed in modern beach environments or are older raised beach deposits formed during the Pleistocene. Economic beach placers are typically $10 \mathrm{~m}$ thick, $1 \mathrm{~km}$ wide and over 5 $\mathrm{km}$ long. A significant part of the iron in sand ilmenite is oxidized to the trivalent state in a natural process affording what is known as weathered ilmenite. Ilmenite sand with a $50 \%-60 \% \mathrm{TiO}_{2}, 15 \%-25 \% \mathrm{FeO}$ and $15 \%$ $25 \% \mathrm{Fe}_{2} \mathrm{O}_{3}$ is a typical feedstock for the $\mathrm{TiO}_{2}$ industries using the sulphate process, but the exhaustion of some large deposits exploited during decades have led to some new deposits being explored for its potential working, some of them in areas of Asia.

\section{Titanium Ores Production, Reserves and Purification}

The term "titanium ore" covers a wide variety of natural or industrial titanium resources that can be used as feed material by $\mathrm{TiO}_{2}$ pigment and titanium metal producer. As we can see in Table 1, the more important commercials titanium ores are basically found in nature as mainly ilmenite (nominally $\mathrm{FeO} \cdot \mathrm{TiO}_{2}$ or $\mathrm{TiFeO}_{3}$ ) containing $40 \%-65 \% \mathrm{TiO}_{2}$, with the rest being mainly ferrous and ferric iron oxides with some amounts of other oxide impurities of chromium, manganese, vanadium, magnesium, aluminum, calcium, silicon and others, depending on its geological history, either as a rock or as sand [14]. The titanium and ferrous and ferric iron content in the

\footnotetext{
${ }^{1}$ Anorthosite and anorthositic gabbro are rock types consisting of $90 \%-100 \%$ and $75 \%-90 \%$ plagioclase feldspar crystals, respectively.
} 
ilmenite may vary significantly as it can be present in its primary stoichiometric form $\left(\mathrm{FeTiO}_{3}\right)$ or as weathered ilmenites and mixtures of both types. The weathered ilmenite is the result from the oxidation and partial dissolution by ground water of the iron, which gradually transforms primary ilmenites to other phases such as pseudorutile $\left(\mathrm{Fe}_{2} \mathrm{Ti}_{3} \mathrm{O}_{9}\right)$. The $\mathrm{TiO}_{2}$ content can even exceed the $60 \%$ when the ore is altered to leucoxene, which is a mixture of rutile or anatase amorphous $\mathrm{TiO}_{2}$ and iron oxides.

Titanium can also be found in nature as rutile, which is a richer form of $\mathrm{TiO}_{2}\left(93 \%-96 \% \mathrm{TiO}_{2}\right)$ which occurs naturally but is not so often found in deposits valid for commercial use, and is often used to feed the $\mathrm{TiO}_{2}$ and finally can be found as leucoxene $\left(\mathrm{Fe}_{2} \mathrm{O}_{3} \cdot \mathrm{nTiO}_{2}\right)$, a natural alteration product of ilmenite, typically containing more than $65 \% \mathrm{TiO}_{2}[6][14]$.

\subsection{Titanium World Mine Production and Reserves}

As we can see in Table 2, in 2009 the major producing regions of ilmenite were South Africa (1.05 Mt), Australia (1.02 Mt), Canada (0.65 Mt), China (0.5 Mt) India (0.42 Mt), Vietnam (0.412 Mt), Norway (0.30 Mt), and Ukranie $(0.30 \mathrm{Mt})$, while the total production was $5.3 \mathrm{Mt}$. On the other hand, the major rutile producers were Australia $(0.266 \mathrm{Mt})$, South Africa $(0.127 \mathrm{Mt})$ and Sierra Leona $(0.06 \mathrm{Mt})$, with a total world production of 0.55 Mt [10].

Nowadays the reserves of ilmenite and rutile are estimated to be about 650 and 42 million metric tons, respectively. For that reason, there is no doubt that ilmenite is the most important titanium resource, and it is sure that this ore will be the main source of titanium in near future. Ilmenite supplies about $91 \%$ of the world's demand for titanium minerals, being its world production of about 5.3 million metric tons in 2009, see Table 2.

In the next decade, global demand for $\mathrm{TiO}_{2}$ is expected to continue increasing at an average rate of about $3 \%$ annually [4] [9]. Growth higher than the average is expected to occur in the Asia region. China in particular is expected to lead world growth in production and consumption. However, the proliferation of small $\mathrm{TiO}_{2}$ pigment plants using the sulphate-route in China has given a very high $\mathrm{TiO}_{2}$ production capacity in China, reaching $1 \mathrm{Mt} / \mathrm{yr}$ by the end of the decade [15]. Growth in aerospace, defense, and industrial uses will strongly influence the demand for titanium metal for the foreseeable future. Based on the announced capacity expansion plans, by 2015, world-wide capacities would be expected to reach 350,000 t/yr [15].

Table 2. Mine production and estimated titanium ore production in thousands of tons [10].

\begin{tabular}{|c|c|c|c|c|c|c|}
\hline & \multicolumn{3}{|c|}{ Ilmenite } & \multicolumn{3}{|c|}{ Rutile } \\
\hline & \multicolumn{2}{|c|}{ Mine production } & \multirow{2}{*}{ Reserves } & \multicolumn{2}{|c|}{ Mine production } & \multirow{2}{*}{ Reserves } \\
\hline & 2009 & $2010\left(^{* *}\right)$ & & 2009 & $2010\left(^{* *}\right)$ & \\
\hline United States & 200 & 200 & 2000 & $\left(^{*}\right)$ & $\left(^{*}\right)$ & \\
\hline Australia & 1020 & 1070 & 100,000 & 266 & 280 & 18,000 \\
\hline Brazil & 43 & 43 & 43,000 & 3 & 3 & 1200 \\
\hline Canada & 650 & 700 & 31,000 & - & - & \\
\hline China & 500 & 600 & 200,000 & - & - & \\
\hline India & 420 & 420 & 85,000 & 20 & 20 & 7400 \\
\hline Madagascar & 47 & 150 & 40,000 & 2 & 6 & NA \\
\hline Mozambique & 283 & 350 & 16,000 & 2 & 2 & 480 \\
\hline Norway & 302 & 320 & 37,000 & - & - & \\
\hline South Africa & 1050 & 1120 & 63,000 & 127 & 130 & 8300 \\
\hline Sri Lanka & 30 & 40 & - & 11 & 12 & NA \\
\hline Ukranie & 300 & 300 & 5900 & 57 & 57 & 2500 \\
\hline Vietnam & 412 & 410 & 1600 & - & - & \\
\hline Sierra Leona & - & - & & 61 & 67 & 3800 \\
\hline Other countries & 34 & 35 & 26,000 & - & - & 400 \\
\hline World total & 5300 & 5800 & 650,000 & 550 & 580 & 42,000 \\
\hline
\end{tabular}

(") United State rutile production and reserves data are included with ilmenite. $\left(^{* *}\right)$ estimated. () Zero. NA Not Available. 


\subsection{Titanium Ore Purification}

Alternative titanium feedstock commercially available are obtained from ilmenite by its purification, as it is described below, to obtain "titania slag" and "synthetic rutile", produced at industrial scale. The limited availability of high quality titanium ores, with high $\mathrm{TiO}_{2}$ and limited iron and heavy metals content (chromium, vanadium, etc.) is threatening the $\mathrm{TiO}_{2}$ business in terms of guaranteed and quality supply and prices, particularly since 2010 .

\subsubsection{Upgrade of Ilmenite to Slag and UGS}

To produce the two main titanium products, titanium dioxide (by sulphate and chloride process) [16] and metallic titanium (Kroll process) [17], and taking into account the exhaustion of some deposits, ilmenite ores are often upgraded for commercial purposes into titania "slag" containing typically $70 \mathrm{wt} \%-90 \mathrm{wt} \% \mathrm{TiO}_{2}$ by electrosmelting processes conducted at very high temperatures (molten state) in electric arc furnaces, where other "main" product is the high purity pig iron (HPPI) of important and specific industrial applications [18]. This process is applied to the rock ilmenite from Eastern Canada and Norway, which is upgraded by a smelting process by important mineral companies, with or without a preliminary pre-reduction stage. The slag obtained from rock ilmenite is commercially supplied to $\mathrm{TiO}_{2}$ manufacturers as a feedstock for the sulphate process, but cannot be used for the chloride $\mathrm{TiO}_{2}$ manufacture due to its relatively high calcium and magnesium content [19]. A further purification of part of the slag produced from rock ilmenite is carried out by thermal treatment [20] [21] and pressure leaching in $\mathrm{HCl}$ affording the "upgraded slag" (UGS), with $95 \%$ of $\mathrm{TiO}_{2}$ and a lower calcium and magnesium content. UGS is a suitable feedstock for the $\mathrm{TiO}_{2}$ chloride process and titanium metal production.

Although the sand ilmenite is often sold to the $\mathrm{TiO}_{2}$ industry as a feedstock for the sulphate process (rarely used for the chloride process which requires a higher $\mathrm{TiO}_{2}$ feedstock such as slag or natural or synthetic rutile) it is also smelted to produce slag by using classical electric furnaces, or a modern DC plasma arc furnace technology. This is the case of the sand ilmenite extracted from several deposits in South Africa and processed to afford a slag with $85 \%-87 \% \mathrm{TiO}_{2}$ which is suitable and sold for use in the $\mathrm{TiO}_{2}$ chloride process, called for that reason as "chloride slag", [22].

\subsubsection{Beneficiation of Ilmenite to Synthetic Rutile}

In the same way, ilmenite ores are also upgraded into "synthetic rutile" products containing $90 \mathrm{wt} \%-96 \mathrm{wt} \%$ $\mathrm{TiO}_{2}$ by processes consisting in reducing the iron oxide and the "leaching" with mineral acids. Although there are a number of commercialized or proposed processes to produce "synthetic rutile", the best known are the Becher and the Benilite process [22].

The Becher process starts with the reduction of the iron in ilmenite almost completely to its metallic form in a rotary kiln with coal at ca. $1200^{\circ} \mathrm{C}$. The reduced ilmenite is processed through a screen and magnetic separation, to remove the char, which is recycled to the kiln. It is then subjected to leaching in a $\mathrm{NH}_{4} \mathrm{Cl}$ solution under aeration to oxidize and precipitate the iron as oxide/hydroxide in fine particles that are separated from the coarser synthetic rutile with hydrociclones to afford the $\mathrm{TiO}_{2}$ beneficiate.

In the Benilite process, the iron content of ilmenite is reduced to the ferrous state with heavy oil in a rotary kiln at $850^{\circ} \mathrm{C}-1100^{\circ} \mathrm{C}$. The reduced ore is leached in digesters with $18 \%-20 \% \mathrm{HCl}$ at $145^{\circ} \mathrm{C}$. The leached material is then washed and calcined, affording the beneficiate. The leaching acid is regenerated and the iron oxide separated as a by-product.

Other processes have either been used or are under development, such as the Rupaque process run at Japan during a number of years, the Austpac process by roasting and leaching with $\mathrm{HCl}$, and the Altair process based on leaching with concentrated chloride solutions. All those process have some similarities with the previously described ones.

\section{Manufacture of Titanium Dioxide Pigments}

In opposition of the popular belief, the most widely used titanium product is not the titanium metal and alloys, but rather is the titanium dioxide $\left(\mathrm{TiO}_{2}\right)$ pigment that provide whiteness and opacity to a vast range of everyday products from coatings and plastics, to inks and even as flux in glass manufacture, filler in paper, rubber industries [15], cosmetics and food. Annually more than 4.5 million $\mathrm{t}$ of $\mathrm{TiO}_{2}$ are produced worldwide [23] and only about $4 \%-5 \%$ is used to produce metallic titanium [24]. 
Titanium dioxide was first discovered in the early 1900s and the manufacture of titanium white for use as a pigment (anatase form) was first reported in 1923 in France, where soon replaced the lithopone ${ }^{2}$ and toxic lead-based pigments in the early 1930 s.

Titanium dioxide pigments are produced from a variety of ores by two different processes: the sulfate process (about $40 \%$ of total $\mathrm{TiO}_{2}$ production) using concentrate sulphuric acid and the chloride process (about $60 \%$ ) using chlorine gas. Both processes differ in their chemistry and raw material requirements. Because the chloride process has some advantages over the traditional sulfate process in cost and waste management, it has dominated the pigment industry in recent times.

\subsection{The Chloride Process}

The chloride process, commercialized by Du Pont in the early 1950s, offers waste disposal, energy and quality advantages over the sulfate process [25]. This process can use a wide range of feedstock, i.e. rutile, synthetic rutile, high-grade ilmenite or slag, depending of the industry but mainly rutile and synthetic rutile $(90 \%-95 \%$ $\mathrm{TiO}_{2}$ ) are used, avoiding the iron sulfate waste problem.

The chloride process begins with the mixing of raw materials with gaseous chlorine at a temperature of around $900^{\circ} \mathrm{C}-1000^{\circ} \mathrm{C}$ in a fluidized bed reactor in the presence of coke as a reducing agent (1) [23]. The resulting gas stream contains titanium tetrachloride $\left(\mathrm{TiCl}_{4}\right)$, oxides of carbon and all the impurity metals from the feedstock in the form of metal chlorides, but impurities such as silica and zirconium may not chlorinated and remain accumulated in the reactor [23] [25]. Significant quantities of gas chlorine are required for low $\mathrm{TiO}_{2}$ content feedstock.

The main chemical reactions of this process are the followings:

$$
\begin{gathered}
2 \mathrm{TiO}_{2}+3 \mathrm{C}+4 \mathrm{Cl}_{2} \rightarrow 2 \mathrm{TiCl}_{4}+2 \mathrm{CO}+\mathrm{CO}_{2} \\
\mathrm{TiCl}_{4} \text { (impure gas) } \rightarrow \mathrm{TiCl}_{4} \text { (pure liquit) } \\
\mathrm{TiCl}_{4}+\mathrm{O}_{2} \rightarrow \mathrm{TiO}_{2}+2 \mathrm{Cl}_{2}
\end{gathered}
$$

The gas stream is contacted with recycled liquid $\mathrm{TiCl}_{4}$ which cools it to a level in at which the other metal chlorides separate out as solids by condensation and chemical treatment. The impurities can be reduced to typically about $10-20 \mathrm{mg} \cdot \mathrm{kg}^{-1}$. The purified $\mathrm{TiCl}_{4}$ goes forward with further cooling to be condensed as a liquid (2) and then fed to a high temperature oxidation reactor where it is reacted with oxygen, above $1500^{\circ} \mathrm{C}$, either in a plasma arc furnace or in a toluene-fired furnace to form titanium dioxide and release the chlorine which is recycled back to the beginning of the reaction (3). Residual chlorine associated with the solid $\mathrm{TiO}_{2}$ is removed by aqueous hydrolysis. Finally the pure titanium dioxide is subjected to a range of chemical surface treatments, milling and drying.

The wastes generated by the chloride process are mainly coke and ore solids that remain un-reacted during the chlorination process. In addition a waste acid solution, usually called iron chloride waste acid, is also generated when the combined stream of un-reacted coke and ore solids, metal chloride solids, is acidified using water or waste hydrochloric acid $(\mathrm{HCl})$ from the reaction scrubber. The metal chloride impurities are generally environmentally harmful, especially the iron chloride, which are removed and neutralized with lime or limestone, and finally sent for disposal via landfill. Curiously, in one chlorine plant in the United States, the chlorine salts are not neutralized, but they are injected into deep exhausted oils well [22].

In the described process the consumption of chlorine is therefore related to the amount of iron oxide presents in the raw material. About one ton of chlorine is required to produce 5 to 6 tons of titanium dioxide pigment (depending on the iron content in the feedstock used consuming the chlorine as ferric chloride and with about one-third of chlorine ending up as hydrogen chloride).

Currently, the chloride process offers tighter product control, is less labor intensive, and is environmentally safer. Currently about 60 percent of the 4.5 million tons of pigment production world-wide is generated by the chlorine process. Although declining in response to concerns about environmentally unacceptable waste, many sulfate plants have introduced innovative techniques deferring their closure.

\subsection{Sulphate Process}

The sulphate process was the first commercialized technology to obtain the titanium dioxide pigment. In this

\footnotetext{
${ }^{2}$ Lithopone is a white pigment composed of a mixture of barium sulfate $(28 \%-30 \%)$ and zinc sulfide $(68 \%-70 \%)$ with trace amounts of zinc oxide.
} 
process, ilmenite $\left(40 \%-60 \% \mathrm{TiO}_{2}\right)$ or titanium slag $\left(72 \%-85 \% \mathrm{TiO}_{2}\right)$ or even a carefully controlled blend, is digested with concentrated sulphuric acid (98\%). A highly-exothermic reaction is initiated by the addition of measured quantities of steam, water and diluted sulphuric acid. The general equation for the digestion reaction (dissolution of the raw material) is the following:

$$
\begin{gathered}
\mathrm{FeTiO}_{3}+2 \mathrm{H}_{2} \mathrm{SO}_{4} \rightarrow \mathrm{TiOSO}_{4}+\mathrm{FeSO}_{4}+\mathrm{H}_{2} \mathrm{O} \text { (Dissolution of the raw material) } \\
\mathrm{TiOSO}_{4}+\mathrm{H}_{2} \mathrm{O} \rightarrow \mathrm{TiO}_{2} \mathrm{n} \cdot \mathrm{H}_{2} \mathrm{O}+\mathrm{H}_{2} \mathrm{SO}_{4}\left(\mathrm{TiO}_{2}\right. \text { precipitation) } \\
\mathrm{TiO}_{2} \mathrm{n} \cdot \mathrm{H}_{2} \mathrm{O} \rightarrow \mathrm{TiO}_{2}+\mathrm{nH}_{2} \mathrm{O}\left(\mathrm{TiO}_{2}\right. \text { calcination and conditioning) }
\end{gathered}
$$

The resulting liquor contains titanyl sulphate $\left(\mathrm{TiOSO}_{4}\right)$ and iron sulphate $\left(\mathrm{FeSO}_{4}\right)$ dissolved in sulphuric acid. If the feedstock used is ilmenite based, a reduction step is required in which iron is added to convert any ferric ions $(\mathrm{Fe} 3+)$ to the ferrous $(\mathrm{Fe} 2+)$ form to aid separation later in the process. Therefore to ensure that all the iron is in dissolution, the liquor is passed through scrap metal (iron reduction step). Then, it passes to a clarification tank where the undissolved ore and solids are allowed to settle. The titanium liquor is then concentrated and hydrolyzed to titanium dioxide hydrated (5).

The titanium dioxide hydrated precipitates from the ferrous sulphate and sulphuric acid is separated by filtration. The iron sulphate is separated from the titanium dioxide production process liquors by concentration and cooling, as we will see with more detail in Section 5.1. After filtration, the hydrated titanium dioxide slurry is sent to a calciner, where the titanium dioxide crystals grow to their final crystalline size and residual water and $\mathrm{H}_{2} \mathrm{SO}_{4}$ are removed (6). The dried titanium dioxide is sent to a finishing phase, which involves any required milling and or chemical treatment, such as surface coating with silica or alumina. Further processing (finishing), is then analogous to the chloride process involving chemical surface treatments (coating), milling and drying operations.

About one ton of raw material (ilmenite or ilmenite + slag) is required to produce 0.5 tons of titanium dioxide pigment.

Finally, we can say that he sulphate process uses a simpler technology and lower grade and cheaper raw materials to produce a form of pigment called anatase (tetragonal, near octahedral), which is preferred over the pigment from the chloride process for use in papers, ceramics and inks. However, the traditional sulphate process produce lower quality products for most applications and large quantities of waste iron sulphate, due to the high concentration of iron presents in the ilmenite used. The exhaustion of some large deposits exploited during decades have led to some new deposits being explored for its potential working but the trend is to feed the $\mathrm{TiO}_{2}$ sulphate sites containing ilmenite with lower $\mathrm{TiO}_{2}$ than in the past.

\section{Properties and Uses of Titanium Dioxide Pigments}

As mentioned above, about $95 \%$ of titanium ore is processed into titanium dioxide which is the most widely used titanium product. $\mathrm{TiO}_{2}$ is a polymorphous and simple inorganic compound, existing in three fundamental crystal forms. All three forms, anatase, rutile and brookite, occur naturally but the latter is rare, and although it has been prepared in the laboratory it is of no commercial interest. Therefore, the main crystal forms commonly available are two, anatase and rutile. Rutile is the most stable form and is thus the most abundant. It has a more compact structure than anatase and this gives rise to important differences in properties between both modifications. Rutile $\mathrm{TiO}_{2}$ has a higher refractive index, higher specific gravity and greater chemical stability than anatase, smelting at $1825^{\circ} \mathrm{C}$. Anatase has no specific melting point as it is irreversibly transformed to rutile before a melting point is reached.

\subsection{Properties}

$\mathrm{TiO}_{2}$ is a simple inorganic compound produced as a pure white powder (known as titanium white). This pigment can be used, in most of its applications, as a pigment to scatter light, because absorbs almost no incident light in the visible region of the spectrum. This pigment scatters light by three mechanisms: reflection from the surface of a crystal, refraction within a crystal, and diffraction, whereby light is bent as it passes near a crystal. Reflection and refraction are maximized by increasing the difference between the refractive index of the pigment and that of the polymer matrix or other material in which it is dispersed. In addition, $\mathrm{TiO}_{2}$ is a good pigment because it has a very high refractive index of 2.70 in comparison with values of only 2.02 and 1.57 for zinc oxide and china clay respectively, as we can see in Table 3 . This means that relatively low levels of the pigment are re- 
quired to achieve a white opaque coating.

This high refractive index gives the potential for producing much greater opacity or hiding power, making $\mathrm{TiO}_{2}$ a much better pigment than the other chemicals mentioned. Light scattering by diffraction is most effective when the pigment diameter is slightly less than half the wavelength of the light to be scattered. Hence, the whiteness of titanium dioxide pigments is a function of particle size. Pigments containing smaller-sized particles lead to finished products (e.g., paints, plastics, etc.) that tend to have a bluish tint; pigments with larger-sized particles cause finished products to have a more yellowish tint [26].

On the other hand, we can see in Table 3 that most rutile pigments have a specific gravity between 3.9 and 4.1, while anatase grades have 3.7 or 3.8. Zinc sulphide and Lithopone $30 \%$ have slightly higher values of specific gravity, but other white pigments are much denser. An important measure of a pigment's potential hiding power can be determined by a simple test whereby it is tinted with a standard black pigment, and assessed using an arbitrary scale. The tinting strength values for rutile titanium pigments range between 1550 and 1850 and for anatase between 1150 and 1350. The best of the other white pigments listed in Table 3, zinc sulphide, is only half as powerful as rutile.

Other important features of titanium dioxide pigments are excellent resistance to chemical attack, good thermal stability and resistance to ultraviolet (UV) degradation. Rutile pigment is more resistant to UV light than anatase, and is preferred for paints, plastics, especially those exposed to outdoor conditions, and inks. On the other hand, anatase pigment has a bluer tone than the rutile type, is less abrasive and is used mainly in indoor paints and in paper, ceramics, rubber and fibers manufacture. One possible explanation for the high abrasion properties of rutile $\mathrm{TiO}_{2}$ pigments is the multiple facets of the pigment particles [26]. Also, anatase reflects more ultraviolet light than rutile, making more ultraviolet light available for optical brighteners. Both rutile and anatase pigments can be made more resistant to photodegradation by coating the pigment particles, which also improves their dispersibility, dispersion stability, opacity and brightness. Anatase is 10 times more active than rutile and responds to slightly different wavelengths [27]. In paper, the advantage of rutile over anatase is less decisive because the light-scattering advantage is partially off-set by a density disadvantage.

Therefore we can say that titanium dioxide is the best white pigment available, but this does not just restrict its use to anything that is white; the opacity is also used in combination with colored pigments to give them the required hiding power they need.

Taking into account the properties above mentioned, the major consumer industries for titanium dioxide pigments are mature sectors in high-resource countries where they are used for surface coatings, paper and paperboard and plastics. In addition, consumption of titanium dioxide tends to be parallel to the general economic trends. World consumption of titanium dioxide by end-use in 2001 was: coatings, 55\%; plastics and rubber, 24\%; paper, $12 \%$; printing inks, $3 \%$; and other, $6 \%$; while in 2005 was: coatings, $58 \%$; plastics and rubber, $23 \%$; paper, $11 \%$; and other, $8 \%$ [23] [28]. Some other uses of titanium dioxide are in catalysts, ceramics, coated fabrics and textiles, floor coverings and roofing granules [29].

According to the American Society for Testing and Materials (ASTM, 1988 [30]) D476-84 standard, four types of titanium dioxide pigment exist [31] [32].

Table 3. Refractive index, Refractive tinting strength and specific gravity of some white pigments.

\begin{tabular}{cccc}
\hline Pigments & Refractive Index & Tinting Strength & Specific Gravity \\
\hline White lead & 2.00 & 100 & 6.7 \\
Zinc oxide & 2.02 & 200 & 5.6 \\
Zinc sulfide & 2.37 & 900 & 4.0 \\
Anatase $\mathrm{TiO}_{2}$ & 2.55 & 1350 & $3.7-3.85$ \\
Rutile $\mathrm{TiO}_{2}$ & 2.70 & 1850 & $3.7-4.2$ \\
China Clay & 1.57 & $<100$ & 2.6 \\
Lithopone 30\% & 1.84 & 300 & 4.3 \\
Antimony Oxide & 2.30 & 400 & 5.7 \\
\hline
\end{tabular}


- Type I (94\% titanium dioxide min.) is a titanium dioxide-anatase pigment that chalks (forms a layer of loose pigment powder on the surface of weathered paint film) freely and is used in white interior and exterior house paints.

- Type II ( $92 \%$ titanium dioxide min.) is a titanium dioxide-rutile pigment with medium resistance to chalking and is used in varying amounts in all types of interior paints, enamels and lacquers.

- Type III ( $80 \%$ titanium dioxide min.) is also a titanium dioxide-rutile pigment with medium resistance to chalking and is used principally in alkyd and emulsion flat wall paints.

- Type IV (80\% titanium dioxide min.) is another titanium dioxide-rutile pigment that has a high resistance and it is used in exterior paints and has excellent durability and gloss retention.

The Japanese grading system, the JIS K5116-1973, specifies four grades of titanium dioxide-rutile, three of which contain at least $92 \%$ titanium dioxide and the fourth contains a minimum of $82 \%$. The type of coating in each grade is also specified [32].

Below, a number of industrial fields where it is necessary to $\mathrm{TiO}_{2}$ and which are the most important applications of this pigment are exposed:

\subsection{Uses}

\subsubsection{Coatings, Plastic and Paint}

The use of titanium dioxide pigment in paint and coating industries is much extended, where other pigments have been substituted. Because coatings are applied in thin layers, a relatively high amount of pigment must be used to achieve hiding. The amount of pigment in a coating is commonly specified as the pigment volume concentration (PVC). Different kinds of paints (high gloss, flat) will have different levels of PVC.

Industrial coatings cover a wide range of services. This includes wood products, metal furniture, coil coatings, appliances and transportation equipment. Automotive and automotive aftermarket coatings are usually considered as a separate business. Automotive finishes have the most critical performance requirements of the industry. These include the need for photodurability, corrosion protection and chip resistance. Pigments suitable for automotive market demands, serve as a benchmark for other less critical applications. Pigment characteristics important to automotive finishes are gloss, gloss retention and hiding power, [33].

Moreover titanium dioxide pigment is used to opacity plastic materials. Un-pigmented plastic is translucent to transparent and therefore not aesthetically appealing. In some applications, $\mathrm{TiO}_{2}$ is used to improve photodurability. The requirements for $\mathrm{TiO}_{2}$ in plastics are good dispersibility in a polymer system, blue undertone and good heat stability [34]. Blue undertone is required because humans perceive bluish whites as cleaner than yellow ones. A few applications, light shades among them, call for yellow undertone pigment because the transmitted light is bluish.

Plastic objects usually have a much lower pigment concentration than coatings because they are usually much thicker than films. Hence, opacity can be achieved with less $\mathrm{TiO}_{2}$. The vast amount of plastic produced, however, makes the plastics industry a major $\mathrm{TiO}_{2}$ user. In this sense, is widely used in plastics construction material as pipes and window blinds, furniture, household items, floor coverings and walls. In stabilized plastics such as polyolefin, $\mathrm{TiO}_{2}$ accelerates yellowing of the plastic [25]. The phenomenon is caused by the reaction of titanium with phenolic groups attached to the antioxidant additives in the plastic. The chemistry involves the base-catalyzed formation of a yellow titanium phenate complex. Suitable organic surface treatments have been shown to reduce or eliminate this effect. Other mechanisms of yellowing not related to $\mathrm{TiO}_{2}$ can be a factor. This includes the effects of smog, ozone and other photoreactions.

\subsubsection{Printing Inks and Paper}

In the field of graphic arts (printing), the ink is usually applied in a much thinner film than a normal coating (less than 100 microns), and for that very fine particles of titanium dioxide are used. The concept of ink spans a wider range of application than the traditional arts of letter-press, gravure and lithographic printing. Inks have performance requirements different from coatings. Ink formulation is adjusted by the printer to meet the specific requirements of drying speed, type of application equipment as well as the nature of the substrate being covered.

For white hiding and high brightness, titanium dioxide is the pigment of choice. The type of $\mathrm{TiO}_{2}$ can affect ink rheology, abrasiveness, gloss and redispersibility. Additional ink applications with $\mathrm{TiO}_{2}$ include inks for wood molding, marking pens and decorative sheets. Ink correction fluid for paper depends on titanium dioxide to hide errors. Inks for concealed writing (scratch-off lottery tickets) likewise use $\mathrm{TiO}_{2}$ because of the superior 
hiding power.

Titanium dioxide is added to high-quality or thin papers to impart brightness and opacity [25]. Because of the rough surface of paper, gloss and photochemical stability are not as important in paper as they are in paint. Consequently, untreated, and less vigorously ground, anatase and rutile pigments can be used. Thus paper pigments tend to be cheaper than paint pigments. Since paper is made in aqueous systems, most of the titanium dioxide is sold to the industry as slurry.

Rutile, because of its higher optical efficiency, is the pigment of choice especially in coated paperboard [25]. The higher abrasiveness of rutile crystals can be overcome by coating them with a mixture of hydrous silica and alumina. An advantage of anatase is its lower absorption of light in the far-violet and near-UV. This result in a blue-white color perceived as pleasing to the eye. Anatase is compatible with the fluorescent brighteners that are quenched by rutile.

The paper industry uses pigment in two applications: wet-end addition and paper coatings. In the wet-end addition, aqueous pigment dispersion is added to the paper pulp [34]. To make pigment particles stick to the fibers, flocculating agents and retention aids are added. Up to $6 \%$ by weight of titanium dioxide can be added in this way without decreasing the strength of the paper.

\subsubsection{Pharmaceutical and Cosmetic Industries}

$\mathrm{TiO}_{2}$ is widely used as a pigment for coloring of different products in pharmaceuticals and cosmetics industries. The main objective is to provide to the final product an appropriate color which will cause pleasant subjective sensations in the final consumer, based on the refraction caused by the pigment added. The characteristics of titanium dioxide provide interesting colors and allow new properties to pharmaceuticals with very small amounts of pigments.

There are many products in this field that contain titanium dioxide, including: shampoos, balms, lotions, creams, soaps, sunscreens, lipsticks, toothpaste, hair dyes, anti-wrinkle treatment, protect baby cream, stretch marks and cellulite treatments, hair treatments, etc.

\subsubsection{Textiles}

Dyeing of synthetic fibers has required more hydrophobic dyes and the development of new techniques to deliberately break the structural regularity and to accept the dye. The titanium dioxide pigment is characterized by high whiteness, good dispersibility, good hiding power, good heat resistance, light resistance and radiation UV. Among the products where they can be applied are: polyester fibers, polyethylene terephthalate (PET), acrylic and polyamide [25]. For this type of application anatase pigment is preferred.

Finally, in the field of synthetics fibers is very used a physical parameter named "Shine", defined as the amount of the reflected light, which is controlled by the amount of titanium dioxide added in the manufacturing process or polymerization; Bright contains $0.06 \%$ titanium dioxide; semi-opaque, $0.3 \%$ titanium dioxide; and opaque, $2 \%$ titanium dioxide.

\subsubsection{Food Industry}

Due to very low toxicity, the $\mathrm{TiO}_{2}$ is widely used in the food industry as coloring. Titanium dioxide is permitted as a food coloring (E171), in the anatase form, by the Spanish Royal Decree 2001/1995 of 7 December [35].

It is often used as an additive in order to decrease or to blend any unwanted color in the food. Normally, in a proportion no upper than $1 \%$ by weight, is used in confectionery, baked, cheeses, icings, toppings, and food supplements. Also it is used to whiten skim milk, getting whiter milk with a creamy texture. Moreover it has been used to enhance the color of codfish, reaching about $1000 \mathrm{ppm}$ of titanium dioxide, without changes in taste of the cooked product [36].

\subsubsection{Titanium Dioxide Nanomaterials}

Significant research into nanotechnology in the last decade has shown promising new applications for titanium dioxide. As an example, titanium dioxide nanoparticles are used in dye-sensitized solar cells ("DSSC"), a relatively new photovoltaic technology which mimics the way in which plants convert sunlight into energy, although in this case the sunlight is transformed into an electrical current [37] [38]. The potential applications are widespread and range from lightweight low-power markets to large-scale applications.

Other areas of research for the application of titanium dioxide nanoparticles are: as an arsenic removal agent 
in water treatment facilities [39] [40], in cancer treatments (ability to target and destroy cancer cells) [41] and in cement containing $\mathrm{TiO}_{2}$ with self-cleaning properties [42].

\section{A Case of Study by the Sulphate Route}

As we said earlier, the manufacture of titanium dioxide pigments by the sulphate method was a process developed at the beginning of last century, with environmental awareness and technological means at the time, far from the concept of sustainability today. In essence, the industrial process had the objective to recover titanium dioxide of the mineral treated and to discard others co-products (mainly iron salts), discharges and waste generated by the cleanest way possible, but without rules set because there was no regulatory legislation related to their management.

Later, a deep investigation of the wastes generated in the industrial process was carried out, resulting in the development of three new co-products (two "ferrous sulphates" and "red gypsum"), as we will see below (Section 5.1.2), which are currently marketed in different fields.

\subsection{Industrial Process}

In the south-western of Spain, $12 \mathrm{~km}$ from the city of Huelva, we can find the only one industry which produces titanium dioxide pigments in Spain. In this industry, in addition to the main $\mathrm{TiO}_{2}$ pigment production, four different co-products and wastes result as a consequence of the treatment of former waste and/or by-products generated throughout the process (see Figure 3). In the Huelva factory, the oldest and most common process for titanium dioxide production is used: the sulphate process. This process uses concentrated sulphuric acid $\left(\mathrm{H}_{2} \mathrm{SO}_{4}\right)$ to dissolve the titaniferous feedstock, ilmenite (around $50 \%$ of $\mathrm{TiO}_{2}$ ) and slag (around $75 \%$ of $\mathrm{TiO}_{2}$ ) [43], which are milled and dried beforehand to aid the digestion process.

A detailed diagram of the production process at the Huelva titanium dioxide factory is shown in Figure 1. This diagram also shows schematically the treatments applied to the two main co-products generated during the process (in addition to the sludge disposed of).

The main steps in the $\mathrm{TiO}_{2}$ production process at the Huelva factory are the following:

1) Digestion of the ore (batch operation). A carefully controlled blend of ilmenite and slag is mixed with highly-concentrated sulphuric acid $(80 \%-95 \%)$ to digest the $\mathrm{TiO}_{2}$-containing feedstock. The equation for the digestion reaction is summarized as:

$$
\mathrm{FeTiO}_{3}+2 \mathrm{H}_{2} \mathrm{SO}_{4} \rightarrow \mathrm{TiOSO}_{4}+2 \mathrm{H}_{2} \mathrm{O}+\mathrm{FeSO}_{4}
$$

2) The resulting liquor contains titanyl sulphate $\left(\mathrm{TiOSO}_{4}\right)$ and both iron sulphates $\left(\mathrm{FeSO}_{4}\right.$ and $\left.\mathrm{Fe}_{2}\left(\mathrm{SO}_{4}\right)_{3}\right)$ dissolved in sulphuric acid. To ensure that all the $\mathrm{Fe}$ is in dissolution, the liquor is passed through scrap metal (iron reduction step).

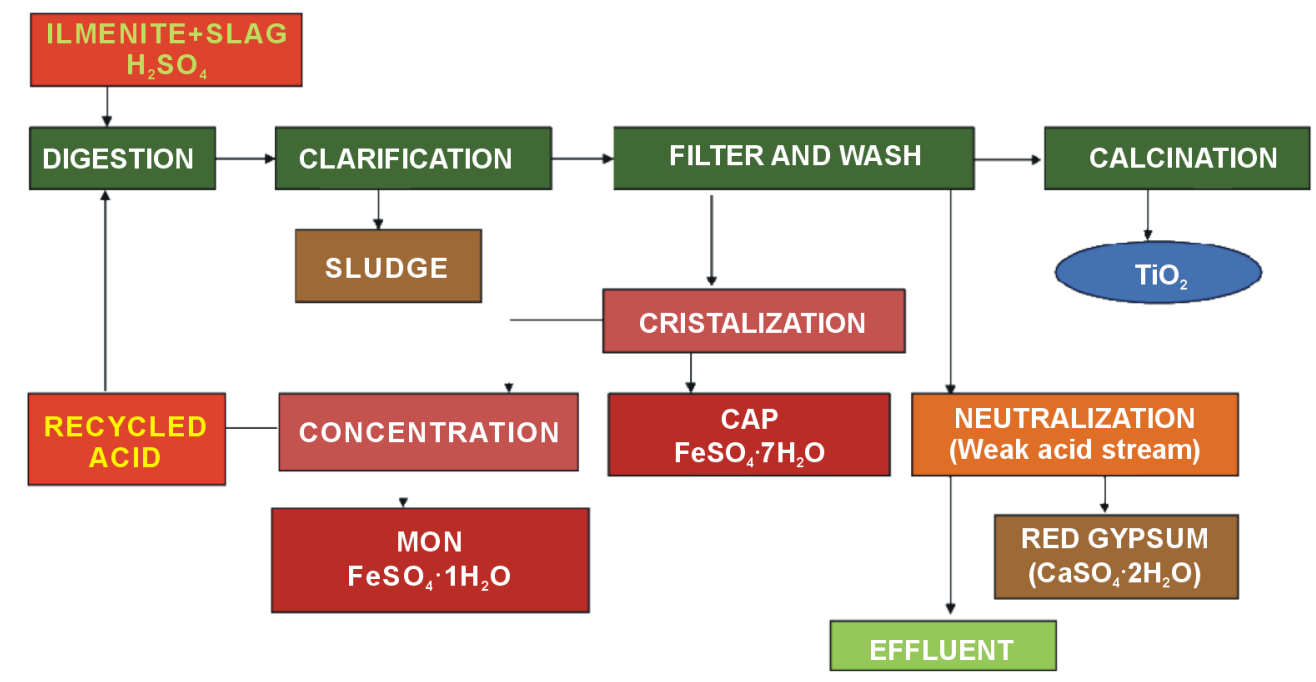

Figure 3. Diagram of the sulphate process used in the Huelva factory. 
3) Clarification of the resulting liquor. The reduced liquor passes to a clarification tank where the un-dissolved solids (sludge) are allowed to settle; afterwards, they are separated from the solution by flocculation (decantation) and filtration. Nowadays, this sludge is neutralised and, finally, disposed of in a controlled disposal area.

4) Titanium dioxide precipitation. The clarified liquor is then hydrolyzed with steam in order to produce the precipitation of hydrated titanium. The addition of a correct amount of titanium-containing seed nuclei to the batch determines the final size and form of the titanium dioxide crystal.

$$
\mathrm{TiOSO}_{4}+\mathrm{H}_{2} \mathrm{O} \rightarrow \mathrm{TiO}_{2} \mathrm{n} \cdot \mathrm{H}_{2} \mathrm{O}+\mathrm{H}_{2} \mathrm{SO}_{4}
$$

5) Hydrated $\mathrm{TiO}_{2}$ separation. The precipitated hydrated $\mathrm{TiO}_{2}$ is separated by vacuum filters (called "Moore filters") from the mother liquor (commonly referred to as "strong" acid, $20 \%-25 \% \mathrm{H}_{2} \mathrm{SO}_{4}$ ). This mother liquor can be considered one co-product of the process, and is treated for the generation of two co-products, as will be detailed later.

6) $\mathrm{TiO}_{2}$ washing. After the separation of the mother liquor, the filtered $\mathrm{TiO}_{2}$ cake is washed with water or a weak acid solution in order to remove the remaining impurities. The water or weak acid solution used in this final wash can be considered a second co-product of the process, and are treated for the generation of a third co-product, as is detailed in the following paragraphs.

7) $\mathrm{The}^{\mathrm{TiO}} 2$ pulp is then placed in rotary kilns for the removal of its water content and some traces of sulphur. The resulting solid is cooled, milled, coated, washed, dried and finely ground ("micronized"), before be packed for commercial distribution.

The historical evolution about the treatment of these wastes, currently co-products, will be treated in more detail in the next section.

On the other hand, we must take into account that the production of titanium dioxide is a NORM (Naturally Occurring Radioactive Material) industrial process, because of Ilmenite present enhanced levels of natural radionuclides from both uranium and thorium series. Some of these radionuclides can be found enriched in the co-products and waste generated. In this sense, a complete and exhaustive study has been carried out in the Huelva's factory, being published for the Nuclear Security Council (CSN) in their technical reports series, 2010. In this report was demonstrated that the annual effective doses received by the personnel performing their working activities in these plants are clearly below $1 \mathrm{mSv} \mathrm{y}^{-1}$.

\subsection{Evolutions of the Environmental Improvements}

Initially, in the early 1970s when the factory of Huelva was designed and built, one of the conditions required to obtain the business license was to discharge in the deep sea the strong acid effluent from the process, containing salts of iron and sulphuric acid, in an area of minimal environmental impact, in this case located in the Gulf of Cadiz at a distance of more than 40 miles from the coast. Oddly enough, this condition was stricter than demanded for other similar industries in Europe, where the strong acid was pumped through an emissary to sea only two kilometers from the coast. This "strong" acid $\left(20 \%-25 \% \mathrm{H}_{2} \mathrm{SO}_{4}\right)$ results from separation of the precipitated $\mathrm{TiO}_{2}$.

Later, at the beginning of 1990s the Council Directive 92/112/EEC of 15 December 1992 [44], established procedures for harmonizing the programmers for the reduction and eventual elimination of pollution from existing industrial establishments. In this Directive:

- Prohibition of the dumping of any solid waste, strong acid waste, treatment waste, weak acid waste, or neutralized waste, is indicated with effect from 15 June 1993.

- As regards S0x, discharges arising from digestion and calcination steps in the manufacture of titanium dioxide should be reduced by 1 January 1995 to a value of not more than $10 \mathrm{~kg}$ of SO${ }_{2}$ equivalent per ton of titanium dioxide produced.

- Solids wastes should be classified taking into account the type of management, attending to their nature.

Taking into account the needs to eliminate the discharges of effluents to the sea, huge technical and environmental accomplishments were carried out in the Huelva's plant with a significant success. For almost five years, the operation parameters in the effluent concentration plant and pigment manufacturing plant were studied and defined, while the right materials were established to be used in the concentration step of strong effluent. This fact is not easy due to the high corrosive power of concentrated sulfuric acid at elevated temperature. Materials such as Teflon, graphite and several alloys of iron are common in this plant, although in some cases; graphite 
has been replaced by tantalum, a more resistant material. Later, a plant with an industrial scale was built, being able to recycle all the strong effluent. The last dumping was made on May 31, 1993.

Firstly, the strong acid, coming from the Hydrated $\mathrm{TiO}_{2}$ separation step, is pumped to crystallisers, where the bulk of the iron sulphate is removed as solid ferrous sulphate heptahydrated, $\mathrm{FeSO}_{4} \cdot 7 \mathrm{H}_{2} \mathrm{O}$. Currently this constitutes the first co-product of the $\mathrm{TiO}_{2}$ process, commonly known as copperas (COP). This product is then extracted, typically by thickening and removal by centrifuge. The crystallised product can be washed with water or acid to produce the desired quality of product.

Secondly, the remaining strong acid is then re-concentrated for reuse in the initial digestion step. This reconcentration is achieved by multi-stage evaporation to concentrate the acid, with the remaining ferrous sulphate in the re-concentrated acid solution being present at the high temperatures employed in the monohydrated rather than the heptahydrated form. This ferrous sulphate monohydrated (MON), $\mathrm{FeSO}_{4} \cdot 1 \mathrm{H}_{2} \mathrm{O}$, second co-product obtained, precipitates in the re-concentration step, forming a solid material which is separated by filtration. We can affirm that the productions of copperas and monohydrate ferrous sulphate are an environmentally benign process and have a positive environmental benefit since every tonne that is produced and used reduces the need for subsequent treatment of the main $\mathrm{TiO}_{2}$ plant effluent, and therefore ilmenite with high iron concentration can be used.

Finally, the third co-product, is formed from the solution resulting from the final stages of $\mathrm{TiO}_{2}$ washings. This solution is also processed by sending it to a new neutralization plant. The neutralisation step consists of adding lime, or limestone, to the weak acid stream, generating a co-product called red gypsum (RG), formed mainly of gypsum and iron hydroxides, according to the following reactions:

$$
\begin{aligned}
& \mathrm{Ca}(\mathrm{OH})_{2}+\mathrm{H}_{2} \mathrm{SO}_{4} \rightarrow \mathrm{CaSO}_{4} \cdot 2 \mathrm{H}_{2} \mathrm{O} \\
& \mathrm{FeSO}_{4}+\mathrm{Ca}(\mathrm{OH})_{2} \rightarrow \mathrm{Fe}(\mathrm{OH})_{2}+\mathrm{CaSO}_{4}
\end{aligned}
$$

The "red gypsum" (RG) is separated by filtration, while the resulting clean water is partially recycled in the process with the remaining water being released into the estuary where the factory is located. The concentrations of pollutants in these waters are substantially lower than the limits fixed by the Spanish government for environmental emissions.

The magnitude of the co-products generated at the Huelva factory are clearly reflected in the following figures: Annually, around 142,000 metric tonnes of raw material are processed ( $80 \%$ ilmenite and $20 \%$ slag), with the generation of 70,000 metric tonnes of RG, 140,000 metric tonnes of COP and 125,000 metric tonnes of MON, [43]. Finally, the magnitude of mud generated annually is around 30,000 metric tonnes, being neutralised and, disposed of in a controlled area, because of that until now economical application has not been found.

In summary, the treatment of the mother liquor co-product leads to the generation of two co-products, copperas (COP) and monohydrate (MON), and the recycling of the resulting clean acid, while the treatment of the weak sulphuric acid coming from the washing of the $\mathrm{TiO}_{2}$ pulp, leads to the generation of a third co-product, red gypsum (RG) and clean water [23] [43].

\subsection{Valorization of Co-Products, Commercial Applications}

Copperas or ferrous sulphate heptahydrated, also called ferrous sulfate, green copperas, green vitriol, vitriol of iron or melanterite, is a compound well known and used for a long time, but in recent times have developed new applications, in order to find markets to the total production of this compound of iron. The classic application has been in the field of agriculture, as supplier of iron to prevent chlorosis in plants, especially in citrus. The presence of iron promotes the formation of chlorophyll, allowing a better plant growth. In addition, is also used as agent to fight the plagues of snails which damage the plantations, especially in the early stages of growth [45].

On the other hand, ferrous sulphate is used in the manufacture of cement as reducing agent of dangerous chromium VI, because the Directive 2003/53/EC of the European Parliament and the Council of 18 June 2003 [46], limits the marketing, use and placing on the market of cement containing derivatives thereof, when hydrated, more than $2 \mathrm{mg} / \mathrm{kg}$ of chromium hexavalent soluble in water, determined as a percentage by mass of dry cement. The purpose of this legislation is to minimize the possible occurrence of allergic contact dermatitis due to the water-soluble chromium VI.

In the field of feedstuffs can be used in different hydrated states and with different humidity content, but always in the ferrous form that is adequate to produce haemoglobin in the animal, especially in the early stages of 
their lives. Monohydrated form is the most adequate, because is a dry product with high iron content, but also can be used dry heptahydrated form or even in some cases as wet form.

In addition, the copperas has been applied for the purification of water by flocculation and for phosphate removal in municipal and industrial sewage treatment plants to prevent eutrophication of surface water bodies and, as ferric sulphate is used to remove mainly the colloidal substances. Ferric sulphate is produced in Huelva from ferrous sulphate in a plant specifically dedicated to this end, either by oxidation using a mixture of sulphuric and nitric acids (in the case of Huelva's factory) or by direct oxidation of ferrous sulphate at elevated temperature and pressure using oxygen and sulphuric acid, according to the following chemical reactions:

$$
\begin{gathered}
6 \mathrm{FeSO}_{4} \cdot 7 \mathrm{H}_{2} \mathrm{O}+2 \mathrm{HNO}_{3}+3 \mathrm{H}_{2} \mathrm{SO}_{4} \rightarrow 3 \mathrm{Fe}_{2}\left(\mathrm{SO}_{4}\right)_{3}+2 \mathrm{NO}+46 \mathrm{H}_{2} \mathrm{O} \\
4 \mathrm{FeSO}_{4} \cdot 7 \mathrm{H}_{2} \mathrm{O}+2 \mathrm{H}_{2} \mathrm{SO}_{4}+\mathrm{O}_{2} \rightarrow 2 \mathrm{Fe}_{2}\left(\mathrm{SO}_{4}\right)_{3}+30 \mathrm{H}_{2} \mathrm{O}
\end{gathered}
$$

For the manufacture of ink and toner for printers, ferrous sulfate is used as raw material for the manufacture of iron pigment, which is previously converted into oxide, either by dehydration and roasting of ferrous sulphate heptahydrated or by roasting of ferrous sulphate monohydrated, according to the following chemical reactions:

$$
\begin{gathered}
\mathrm{FeSO}_{4} \cdot 7 \mathrm{H}_{2} \mathrm{O} \rightarrow \mathrm{FeSO}_{4} \cdot \mathrm{H}_{2} \mathrm{O}+6 \mathrm{H}_{2} \mathrm{O} \\
4 \mathrm{FeSO}_{4} \cdot \mathrm{H}_{2} \mathrm{O}+\mathrm{O}_{2} \rightarrow 2 \mathrm{Fe}_{2} \mathrm{O}_{3}+4 \mathrm{SO}_{3}+\mathrm{H}_{2} \mathrm{O}
\end{gathered}
$$

On the other hand, monohydrate, commercially known as Sulfafer, is a mixture of ferrous sulfate monohydrated, with different minority metal sulfate and sulfuric acid. It is a product obtained with the recovery of the effluents that originally were discharged to the sea, being necessary to find it new applications. In the manufacture on sulphuric acid, has been used as raw material mixed with pyrite (in roasting plants). It is an expensive process because it needs a lot of energy and therefore is not the best option for reuse it.

Moreover, in the agricultural field multiple applications have been searched, taking advantage of the contribution of three main components: The iron in ferrous state, directly assimilated by plants, the sulfuric acid which allows the solubilization of other cations such as magnesium or phosphorus, and finally other metals such as zinc, copper, and manganese which are essential trace elements in plant development. This use has allowed the marketing of different granulated products such as fillmag (ferrous sulphate with some magnesium sulfate), tiomag (magnesium sulphate with some ferrous sulfate), fosfermag (ferrous sulphate with assimilable phosphorus) or PKMag (ferrous sulphate with assailable phosphorus and potassium), all of them highly valued in the field of agriculture.

In alkaline soil, the MON can be used directly in appropriate doses, allowing the acidification of the soil and mix with manure which can make compost produce much quickly, because the presence of free acid accelerates the decomposition of organic matter and at the same time gives good agronomic properties due to the addition of a significant amount of iron that can be assimilated easily for plants.

For the red gypsum, the consulted literature shows that studies about the potential valorization of red gypsum are quite limited. In this regard, it can be pointed out the use of the red gypsum, together with other wastes (lime, basic steel slag and blast furnace slag) to replace some parts of cement as a binder, first in the manufacturing of paving blocks [47], or in the manufacturing of low resistance materials for certain applications (covering trenches or filling of mines) [48]. In addition, we have studied the applicability of the red gypsum as an inhibitor in soil erosion [49] for the inmobilisation of heavy metals in soils [50].

On the other hand, taking into account the composition of this co-product $(\mathrm{RG})$ and that the natural gypsum is added to clinker, between $3 \%$ and $5 \%$, as a set retardant for commercial cements, we have analyzed the possibility of replacing natural gypsum by red gypsum in the manufacturing of cements [51].

Finally, for the waste sample (SLUDGE) generated in the industrial process we can say that currently, the factory of $\mathrm{TiO}_{2}$ production and the University of Huelva have carried out several research projects, about the potential applications of these wastes in different fields such as agriculture, civil engineering, building construction, etc. In summary, we can affirm that in the production plant of titanium dioxide in Spain the recycling strategy is widely applied.

\section{Acknowledgements}

This research has been partially supported by the Government of Andalusia's project "Characterization and modelling of the phosphogypsum stacks from Huelva for their environmental management and control" (Ref.: RNM-6300) and by National Institution of Higher Education, Science, Technology and Innovation of the Re- 
public of Ecuador-(SENESCYT for its acronym in Spanish). The authors would like to acknowledge the financial support received from the company Tioxide-Huelva by the research projects "Valorization of red gypsum from the industrial production of titanium dioxide" (PROFIT, CIT-310200-2007-47) and "Applications of red gypsum and Tionite waste in commercial applications". The authors also thank to the technical staff for the advisory provided in the explanation of the results.

\section{References}

[1] Budinski, K.G. (1988) Surface Engineering for Wear Resistance. Prentice Hall, Englewood Cliffs, 420.

[2] Knittel, D. (1983) Titanium and Titanium Alloys. In: Grayson, M., Ed., Encyclopedia of Chemical Technology, 3rd Edition, John Wiley and Sons, Hoboken, 98-130.

[3] Rudnick, R.L. and Gao, S. (2003) Composition of the Continental Crust. In: Rudnick, R.L., Ed., Treatise of Geochemistry, Vol. 3, Elsevier, Amsterdam, 1-64.

[4] Gambogi, J. (2009) Titanium, 2007 Minerals Yearbook. US Geological Survey, U.S. Government Printing Office, Washington DC, 195.

[5] Stwertka, A. (1998) Guide to the Elements. Revised Edition, Oxford University Press, London.

[6] Williams, V.A. (1990) WIM 150 Detrital Heavy Mineral Deposit. In: Hughes, F.E., Ed., Geology of the Mineral Deposits of Australia and Papua New Guinea, Monograph 14, Australasian Institute of Mining and Metallurgy, 1609-1614.

[7] Whitehead, J. (1983) Titanium Compounds (Inorganic). In: Grayson, M., Ed., Encyclopaedia of Chemical Technology, 3rd Edition, John Wiley and Sons, Hoboken, 131-176.

[8] Force, E.R. (1991) Geology of Titanium-Mineral Deposits. Geological Society of America Special Paper, $259,112$. http://dx.doi.org/10.1130/SPE259-p1

[9] Gambogi, J. (2010) Titanium and Titanium Dioxide, Mineral Commodity Summaries. US Geological Survey, U.S. Government Printing Office, Washington DC, 195.

[10] Gambogi, J. (2011) Titanium and Titanium Dioxide, Mineral Commodity Summaries. US Geological Survey, U.S. Government Printing Office, Washington DC, 195.

[11] Adams, R. (1994) The World Market for $\mathrm{TiO}_{2}$ Feedstocks. Minerals Industry International, 9-14.

[12] Wallis, D.S. and Oakes, G.M. (1990) Heavy Mineral Sands in Eastern Australia. In: Hughes, F.E., Ed., Geology of the Mineral Deposits of Australia and Papua New Guinea, Vol. 14, Australasian Institute of Mining and Metallurgy Monograph, 1599-1608.

[13] Baxter, J.L. (1977) Heavy Mineral Sand Deposits of Western Australia. In: Hughes, F.E., Ed., Geology of the Mineral Deposits of Australia and Papua New Guinea, Australasian Institute of Mining and Metallurgy Monograph, Vol. 14, 1587-1590.

[14] Barksdale, J. (1966) Titanium, Its Occurrence, Chemistry, and Technolog. 2nd Edition, The Roland Press Company, New York.

[15] Zhang, W., Zhu, Z. and Cheng, C.Y. (2011) A Literature Review of Titanium Metallurgical Processes. Hidrometallurgy, 108, 177-188.

[16] Kischekewitz, J., Griebler, W.D. and Liedekerke, M. (1998) White Pigments. In: Buxbaum, G., Ed., Industrial Inorganic Pigments, 2nd Edition, Wiley-VCH, Weinheim, 43-82.

[17] Ikeshima, T. (1985) Recents Developments in Titanium Sponge Production. In: Lutjerng, G., Zwicker, U. and Bunk, W., Eds., Titanium Science and Technology, DGM-Deutsche Gesellschat für Materialkunde, Oberursal, 3-14.

[18] Pourabdoli, M., Raygan, S., Abdizadeh, H. and Hanaei, K. (2006) Production of High Titania Slag by Electro-Slag Crucible Melting (ECSM) Process. International Journal of Mineral Processing, 78, 175-181.

[19] Battle, T.P., Nguyen, D. and Reeves, J.W. (1993) The Processing of Titanium-Containing Ores. In: Reddy, R.G. and Weizenback, R.N., Eds., The Paul E. Queneau International Symposium: Extractive Metallurgy of Copper, Niquel and Cobalt, Vol. 1, TMS, Warrendale, 925-943.

[20] Borowiec, K., Grau, A., Gueguin, M. and Turgeon, J. (2003) $\mathrm{TiO}_{2}$ Containing Product Including Rutile, Pseudo-Brookite and Ilmenite. US Patent No. 6531110. http://www.freepatentsonline.com/6531110.html

[21] Borowiec, K., Grau, A., Gueguin, M. and Turgeon, J. (1998) Method to Upgrade Titania Slag and Resulting Product. US Patent No. 5830420. http://www.freepatentsonline.com/5830420.html

[22] Filippou, D. and Hudon, G. (2009) Iron Removal and Recovery in the Titanium Dioxide Feedstock and Pigment Industries. Minerals, Metals and Materials Society, 61, 36-42. http://dx.doi.org/10.1007/s11837-009-0150-3

[23] McNulty, G.S. (2007) Production of Titanium Dioxide. Plenary Lecture. NORM V International Conference, Sevilla, 
19-22 March 2007, 169-188.

[24] Rosebaum, J.B. (1982) Titanium Technology Trends. Journal of the Minerals, Metals, and Materials Society, 34, 7680 .

[25] Braun, J.H., Baidins, A. and Marganski, R.E. (1992) $\mathrm{TiO}_{2}$ Pigment Technology: A Review. Progress in Organic Coatings, 20, 105-138. http://dx.doi.org/10.1016/0033-0655(92)80001-D

[26] Allen, A. and Gergely, J.S. (1998) Reaction of Titanium Chloride with Aluminum Compound, Oxygen and Boron Oxide. http://www.google.com/patents?id=3iAaAAAAEBAJ

[27] Braun, J.H. (1997) Titanium Dioxide-A Review. Journal of Coatings Technology, 69, 59-72.

[28] Linak, E. and Inoguchi, Y. (2005) Chemical Economics Handbook: Titanium Dioxide. SRI Consulting, Menlo Park.

[29] Gambogi, J. (2005) US Geological Survey Mineral Commodity Summaries-Titanium and Titanium Dioxide. U.S. Government Printing Office Reston, Reston, 178-179.

[30] ASTM (1988) Standard Specification for Titanium Dioxide Pigments. In: Storer, R.A., Cornillit, J.L., Savini, D.F., et al., Eds., 1988 Annual Book of ASTM Standards: Paint-Pigments, Resins, and Polymers, American Society for Testing and Maerials, Philadelphia, 100-101.

[31] Schurr, G.G. (1981) Paint. In: Mark, H.F., Othmer, D.F., Overberger, C.G., Seaborg, G.T. and Grayson, N., Eds., Kirk-Othmer Encyclopedia of Chemical Technology, John Wiley \& Sons, New York, 742.

[32] Fisher, J. and Egerton, T.A. (2001) Titanium Compounds, Inorganic. In: Kirk-Othmer Encyclopedia of Chemical Technology, John Wiley \& Sons, New York.

[33] Huntsman Pigments (2008) The Way forward for Titanium Dioxide? Plastics, Additives and Compounding, 10, 36-37, 39.

[34] Alince, B. (1989) Colloidal Particle Deposition on Pulp Fibers. Colloids and Surfaces, 39, 39-51. http://dx.doi.org/10.1016/0166-6622(89)80177-5

[35] Royal Decree 2001/1995 of 7th December 1995 Approving the Positive List of Colours Authorised for Use in the Preparation of Foodstuffs and Their Conditions of Use. BOE, Spanish Government, Spain.

[36] Meacock, G., Taylor, K.D.A., Knowles, M.J. and Himonides, A. (1997) The Improved Whitening of Minced Cod Flesh Using Dispersed Titanium Dioxide. Journal of the Science of Food and Agriculture, 73, 221-225. http://dx.doi.org/10.1002/(SICI)1097-0010(199702)73:2<221::AID-JSFA708>3.0.CO;2-U

[37] Durrant, J.R., Haque, S.A. and Palomares, E. (2004) Towards Optimisation of Electron Transfer Processes in Dye Sensitised Solar Cells. Coordination Chemistry Reviews, 248, 1247-1257. http://dx.doi.org/10.1016/j.ccr.2004.03.014

[38] Kron, G., Egerter, T., Nelles, G., Yasuda, A., Werner, J.H. and Rau, U. (2002) Electrical Characterisation of Dye Sensitised Nanocrystalline $\mathrm{TiO}_{2}$ Solar Cells with Liquid Electrolyte and Solid-State Organic Hole Conductor. Proceedings of Symposium P on Thin Film Materials for Photovoltaics, Thin Solid Films, 403-404, 242-246.

[39] Nabi, D., Aslam, I. and Qazi, I.A. (2009) Evaluation of the Adsorption Potential of Titanium Dioxide Nanoparticles for Arsenic Removal. Journal of Environmental Sciences, 21, 402-408. http://dx.doi.org/10.1016/S1001-0742(08)62283-4

[40] Xu, Z., Qi, L., Shian, G. and Shang, J.K. (2010) As(III) Removal by Hydrous Titanium Dioxide Prepared from OneStep Hydrolysis of Aqueous $\mathrm{TiCl}_{4}$ Solution. Water Research, 44, 5713-5721.

[41] Lagopati, N., Kitsiou, P.V., Kontos, A.I., Venieratos, P., Kotsopoulou, E., Kontos, A.G., Dionysiou, D.D., Pispas, S., Tsilibary, E.C. and Falaras, P. (2010) Photo-Induced Treatment of Breast Epithelial Cancer Cells Using Nanostructured Titanium Dioxide Solution. Journal of Photochemistry and Photobiology A: Chemistry, 214, 215-223.

[42] Maury, A. and De Belie, N. (2010) State of the Art of $\mathrm{TiO}_{2}$ Containing Cementitious Materials: Self-Cleaning Properties. Materiales de Construcción, 60, 33-50.

[43] Gázquez, M.J., Bolívar, J.P., Garcia-Tenorio, R. and Vaca, F. (2009) Physicochemical Characterization of Raw Materials and Co-Products from the Titanium Dioxide Industry. Journal of Hazardous Materials, 166, 1429-1440. http://dx.doi.org/10.1016/j.jhazmat.2008.12.067

[44] Council Directive 92/112/EEC of 15 December 1992 on Procedures for Harmonizing the Programmes for the Reduction and Eventual Elimination of Pollution Caused by Waste from the Titanium Dioxide Industry.

[45] Orihuela, D.L. and Marijuan, J.L. (2003) Sulfatos de hierro: Su uso agrícola. University of Huelva, Huelva (In Spanish).

[46] Directive 2003/53/EC of the European Parliament and of the Council of 18 June 2003 Amending for the 26th Time Council Directive 76/769/EEC Relating to Restrictions on the Marketing and Use of Certain Dangerous Substances and Preparations (Nonylphenol, Nonylphenol Ethoxylate and Cement). Official Journal of the European Union, 178, 24-27.

[47] Hughes, P.N., Glendinning, S., Manning, D.A.C. and Noble, B.C. (2010) Production of "Green Concrete" Using Red Gypsum and Waste. Proceedings of the ICE-Engineering Sustainability, 163, 137-146. 
[48] Claisse, P., Ganjian, E. and Tyrer, M. (2008) The Use of Secondary Gypsum to Make a Controlled Low Strength Material. The Open Construction and Building Technology Journal, 6, 294-305. http://dx.doi.org/10.2174/1874836800802010294

[49] Hodson, M.E., Valsami-Jones, E., Cotter-Howells, J., Dubbin, A.J., Kemp, A.J., Thornton, I. and Warren, A. (2001) Effect of Bone Meal (Calcium Phosphate) Amendments on Metal Release from Contaminated Soils-A Leaching Column Study. Environmental Pollution, 112, 233-243.

[50] Fauziah, I., Zauyah, S. and Jamal, T. (1996) Characterizaton and Land Applicaton of Red Gypsum: A Waste Product from the Titanium Dioxide Industry. Science of the Total Environment, 188, 243-251. http://dx.doi.org/10.1016/0048-9697(96)05179-0

[51] Gázquez, M.J., Bolívar, J.P., Vaca, F., Garcia-Tenorio, R. and Mena-Nieto, A. (2011) Use of the "Red Gypsum" Industrial Waste as Substitute of Natural Gypsum for Commercial Cements Manufacturing. Materiales de Construcción, 62, 183-198. http://dx.doi.org/10.3989/mc.2011.63910 